\title{
Anatomosurgical Study of the Marginal Mandibular Branch of the Facial Nerve for Submandibular Surgical Approach
}

\author{
Marcus WOLTMANN ${ }^{1}$ \\ Ricardo de FAVERI ${ }^{2}$ \\ Emerson Alexandre SGROTT² \\ ${ }^{1}$ Department of Oral and Maxillofacial Surgery, Faculty of Dentistry, \\ Regional University of Blumenau (FURB), Blumenau, SC, Brazil \\ ${ }^{2}$ Department of Anatomy, Faculty of Dentistry, University of Vale do Itajaí (UNIVALI), Itajaí, SC, Brazil
}

\begin{abstract}
The purpose of this study was to estimate the distance from the mandibular marginal branch of the facial nerve to the inferior margin of the mandible in order to determine the best and safest location to approach the posterior mandibular region. Forty-five hemi-faces of 27 Brazilian adult cadavers were dissected and the distance between the mandibular marginal branch and the inferior margin of the mandible was measured. The number of marginal branches and anastomoses with other branches of the facial nerve was also recorded. The evaluation of the anatomic pieces showed 1 to 3 branches of the marginal mandibular branch, anastomoses with the buccal and cervical branches of the facial nerve and distances between $-1.3 \mathrm{~cm}$ to $+1.2 \mathrm{~cm}$ from the inferior margin of the mandible. In $57.7 \%$ of the cases, the nerve passed superiorly and along the length of the inferior margin of the mandible. Based on the findings of the present anatomosurgical study, it may be recommended an incision $3 \mathrm{~cm}$ below the inferior margin of the mandible associated to a careful dissection in planes and flap retraction. This is expected to reduce the risk of neuropraxia of the marginal mandibular nerve making the submandibular incision a safe approach.
\end{abstract}

Key Words: facial nerve, marginal mandibular branch, submandibular approach.

\section{INTRODUCTION}

The facial or VII cranial nerve is a mixed nerve composed of both motor and sensory branches and is responsible for the motor innervation of facial expression muscles, lachrymal secretion and partial control of the gustatory sensation (1).

The marginal mandibular branch of the facial nerve is responsible for the motor function of the depressor anguli oris, the depressor labii inferioris, the inferior fibers of the orbicularis oris and the mentalis muscles (2-4). Due to its location, this branch can occasionally be damaged during cervical surgeries, parotidectomies, open reductions of mandibular angle fractures, rhytidoplasties and other surgeries confined to the submandibular region (5).

Damaging of the facial nerve can cause salivary incontinence and esthetic impairment due to an alteration in the balance of the musculature around the lower lip (4), preventing lateral and downwards movements and lower lip inversion (6).

In view of the possibility of injuring the nerve during mandibular angle and body surgeries, this paper presents data from an anatomic study of the marginal mandibular branch of the facial nerve that might be useful for performing the submandibular approach. 


\section{MATERIAL AND METHODS}

This study used 45 facial halves of 27 Brazilians adults cadavers fixed in $10 \%$ formalin solution obtained from the Laboratory of Anatomy of University of Vale do Itajaí.

The facial halves were dissected through divulsion of the skin, subcutaneous tissue, platysma muscle and superficial layer of deep cervical fascia. The marginal mandibular, cervical and buccal branches of the facial nerve were identified and individualized.

The cadavers were positioned in dorsal decubitus, with the mandible perpendicular to the coronal plane. Measurement of the lower portion of the marginal mandibular branch (more caudal point) was performed

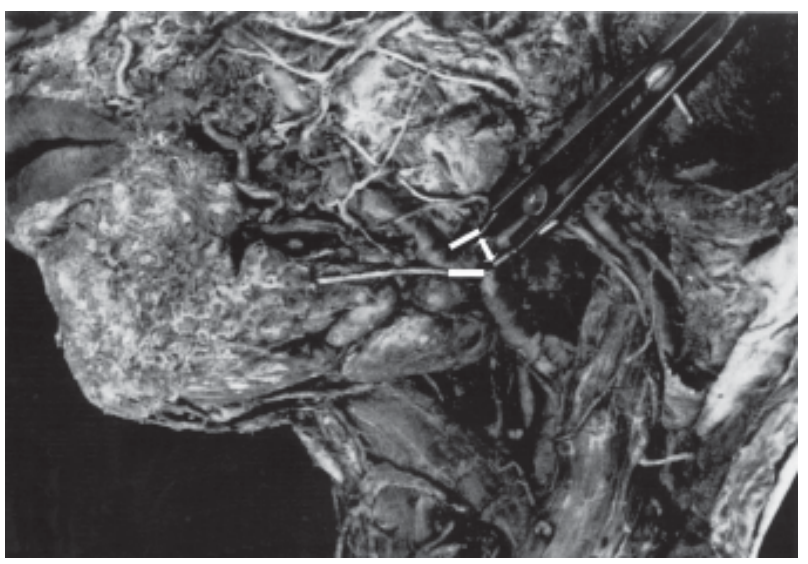

Figure 1. Measurement of the greatest distance from the marginal mandibular branch to the inferior margin of the mandible with compass (arrow and lines).

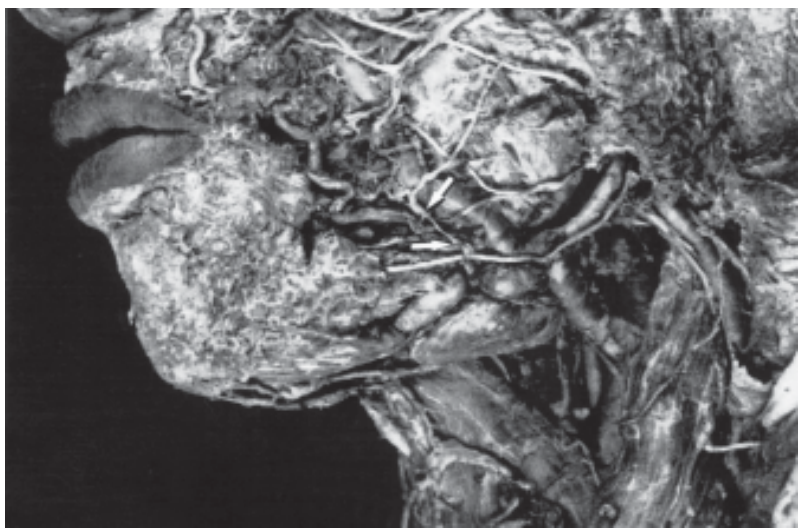

Figure 2. Anastomoses between the buccal and marginal mandibular branches of the facial nerve (arrows). in relation to the inferior mandibular margin (Fig. 1), regardless of its superior or inferior position in relation to the mandibular margin. A compass was positioned perpendicular to the inferior border of the mandible, in such a way that the most trustworthy possible measure was obtained. When the mandibular nerve was located superiorly to the mandibular margin, the measure (in centimeters) received the negative signal; the signal was positive if it was otherwise.

The number of branches of the marginal mandibular nerve was also recorded, as well as the presence of anastomoses with the buccal and cervical branches of the facial nerve (Figs. 2 and 3).

Data were analyzed in a descriptive manner by means of a demographic statistical tabulation because the goals of the study were to assess the largest distance between the marginal mandibular nerve and the inferior margin of the mandible, as well as the number of branches and anastomoses, and correlate these variables to the submandibular approach in order to determine the best location for demarcation of the submandibular incision.

\section{RESULTS}

On average, 1 to 3 branches of the marginal mandibular nerve were observed. One branch was found in 14 cases (31.11\%), 2 branches in 27 cases (60\%) and 3 branches in 4 cases (8.88\%).

The marginal mandibular branch anastomosed with the buccal branch in 19 cases (42.22\%) and with the cervical branch in 10 cases (22.22\%). In 16 cases

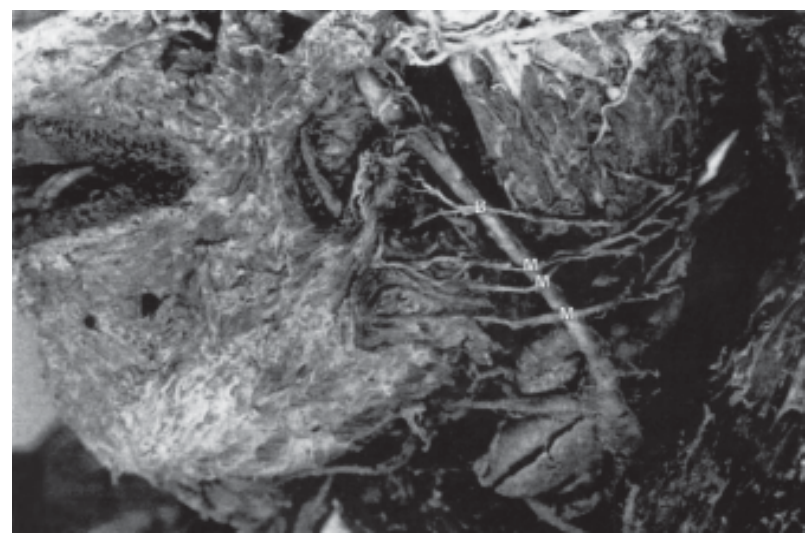

Figure 3. Presence of three marginal mandibular branches (M) and one buccal branch (B). 
(35.55\%), no anastomoses among facial branches were found.

The distances from the marginal mandibular nerve to the inferior margin of the mandible ranged from $-1.3 \mathrm{~cm}$ to $+1.2 \mathrm{~cm}$. In 26 cases (57.7\%) the nerve was found superiorly to the mandibular margin and in the other 19 cases (43.3\%) the nerve was located below the inferior margin of the mandible.

\section{DISCUSSION}

Paralysis of the muscles of facial expression resulting from marginal mandibular branch lesion in surgeries causes esthetic and sometimes functional deformities, with the loss of labial tonus $(2,7)$.

The position of the patient's head is an important factor to consider during the submandibular incisions, and the mandible should always be placed the most perpendicular to the patient's coronal plane as possible, allowing the surgeon a better visualization and a more correct demarcation of the incision. In this study, this was a determinant factor during the measurement of the marginal mandibular branch in the cadavers.

A mistakenly placed surgical incision increases the risk of neurotmesis or neuropraxia of the marginal mandibular branch and the possibility of an unaesthetic postoperative scar.

One to three marginal mandibular branches, with a prevalence of 2 branches in $60 \%$ of the cases, and anastomoses with buccal (42.22\%) and cervical (22.22\%) branches were found. These findings are consistent with those of previous studies (4,5,8-10).

Wang et al. (5) dissected 120 Chinese hemi-faces and found 1 to 4 marginal mandibular branches; most cases had 2 branches (50\%), followed by 1 branch (32\%), 3 branches (13\%) and 4 branches (3\%).The authors also observed anastomoses between buccal and marginal mandibular branches in 59\% of the specimens and between cervical and marginal mandibular branches in $12 \%$ of the cases.

The marginal mandibular branch measurements recorded in the present study ranged between -1.3 and $+1.2 \mathrm{~cm}$. In almost $60 \%$ of the cases the nerve was totally superior to the mandibular margin while in nearly $40 \%$ of the cases it was below the mandible. Ziarah and Atkinson (11) dissected 76 human facial halves and also found marginal mandibular nerve distances to the inferior margin of the mandible no greater than $1.2 \mathrm{~cm}$, but in
$53 \%$ of the cases the nerve was found below the inferior margin of the mandible. On the other hand, Wang et al. (5) found values varying from 0 to $3 \mathrm{~cm}$, and in $95.64 \%$ the nerve passed 0-2 $\mathrm{cm}$ away below the inferior margin of the mandible.

The findings of anatomic studies have agreed about the measurements proposed by Risdon's technique, with an incision 3 to $5 \mathrm{~cm}$ long and $2 \mathrm{~cm}$ below the inferior border of the mandible (11-13). Other authors have recommended that the incision should be made at larger distances. In a previous study (12) a null index of neuropraxia was obtained when incisions were made $3.5 \mathrm{~cm}$ below the inferior border of the mandible, while nearly $56 \%$ of the patients presented neuropraxia after Risdon's incision. Wang et al. (5) also recommend an incision to a distance of at least $3 \mathrm{~cm}$ far from the inferior margin of the mandible based on their findings that in 4.34\% cases the marginal mandibular branch passed between 2.1 and $3 \mathrm{~cm}$ below the inferior margin of the mandible.

The risk of neuropraxia is the major concern of submandibular incision because it can lead to sequela such as salivary incontinence and esthetic impairment due to an alteration in the balance of the musculature around the lower lip (4), preventing lateral and downwards movements and lower lip inversion (6).

Although values greater than $+1.2 \mathrm{~cm}$ were not found in this study, our findings are consistent with those of Wang et al. (5), who recommends an incision $3 \mathrm{~cm}$ below the inferior margin of the mandible because they found cases of marginal mandibular branches passing between 2.1 and $3 \mathrm{~cm}$ below that reference point. The more caudal is the incision, the lesser are the risks of neuropraxia. Most cases are due to traumatic retraction of the tissues and compressive edema. They do not result from a direct nerve injury because the access is made in planes and, whenever the nerve is identified during surgery, it is protected and retracted together with the flap.

Most neuropraxias are reversible and are predominantly caused by compression of the nerve (3), especially in high condylar fractures because of tissue retraction. Thus, care must be taken during open reduction of the condyle in order not to keep the flap retracted during throughout the procedure (14).

Another important factor to be considered is that, in case of direct injury of the marginal mandibular branch, the patient will not necessarily present permanent 
neuropraxia because, as seen, the marginal mandibular branch usually presents more than one branch and the anastomoses with other nerves could partially compensate for the interruption of the neural impulse.

Therefore, it is important to emphasize the importance of the correlation between the anatomic and surgical findings and the correct placement of the submandibular incision (15). Data from the specimens evaluated in this study are similar to those of previous investigations carried out in different populations. Based on the findings of the present anatomosurgical study, it may be recommended an incision $3 \mathrm{~cm}$ below the inferior margin of the mandible associated to a careful dissection in planes and flap retraction. This is expected to reduce the risk of neuropraxia of the marginal mandibular nerve making the submandibular incision a safe approach.

\section{RESUMO}

O objetivo deste estudo foi estimar a distância do ramo marginal mandibular do nervo facial até a margem inferior da mandíbula determinando a melhor e mais segura localização para se acessar a região posterior de mandíbula. Quarenta e cinco hemi-faces de 27 cadáveres brasileiros adultos foram dissecadas e a mensuração da distância foi realizada. O número de ramos do nervo marginal mandibular e as anastomoses com outros ramos do nervo facial foi registrado. A avaliação das peças anatômicas revelou de 1 a 3 ramos do ramo marginal mandibular, anastomoses com os ramos bucal e cervical do nervo facial e distâncias entre $-1.3 \mathrm{~cm}$ a +1.2 cm da margem mais inferior da mandíbula, com a predominância (57.7\%) de casos em que o nervo passava superiormente, e ao longo da margem inferior da mandíbula. Com base nos achados deste estudo anatomo-cirúrgico, pode-se recomendar uma incisão $3 \mathrm{~cm}$ abaixo da margem inferior da mandíbula associada à dissecação cuidadosa em planos e retração do retalho. Acreditase que essa abordagem seja capaz de reduzir o risco de neuropraxia do nervo marginal mandibular, tornando a incisão submandibular um acesso seguro.

\section{ACKNOWLEDGEMENTS}

The authors are grateful to the staff of the Department of Anatomy of the University of Vale do Itajaí, SC, Brazil and to Prof. Dr. Hercílio Pedro da Luz, DDS, Full Professor of this Department, for their valuable collaboration.

\section{REFERENCES}

1. Gray H, Williams PL, Bannister LH. Gray’s anatomy: the anatomical basis of medicine and surgery. 38th ed. New York: Churchill Livingstone; 1995.

2. Hussain G, Manktelow RT, Tomat LR. Depressor labii inferioris resection: an effective treatment for marginal mandibular nerve paralysis. Br J Plast Surg 2004;57:502-510.

3. Ichimura K, Nibu K, Tanaka T. Nerve paralysis after surgery in the submandibular triangle: review of University of Tokyo Hospital experience. Head Neck 1997;19:48-53.

4. Kennedy PJ, Poole AG. Excision of submandibular gland: minimizing risk of nerve damage. Aust $\mathrm{N} \mathrm{Z} \mathrm{J} \mathrm{Surg}$ 1989;59:411-414.

5. Wang TM, Lin CL, Kuo KJ, Shih C. Surgical anatomy of mandibular ramus of the facial nerve in Chinese adults. Acta Anat (Basel) 1991;142:126-131.

6. Moffat DA, Ramsden RT. The deformity produced by palsy of the marginal mandibular branch of the facial nerve. $J$ Laryngol Otol 1977;41:401-416.

7. Ellenbogen R. Pseudo-paralysis of the mandibular branch of the facial nerve after platysmal face-lift operation. Plast Reconstr Surg 1979;63:364-368.

8. David WN, Gingrass RP. Anatomy of mandibular branches of the facial nerve. Plast Reconst Surg 1979;64:479-482.

9. Gosain AK. Surgical anatomy of the facial nerve. Clin Plast Surg 1995;22:241-251.

10. Savary V, Robert R, Rogez JM, Armstrong O, Leborgne J. The mandibular marginal ramus of the facial nerve: an anatomic and clinical study. Surg Radiol Anat 1997;19:69-72.

11. Ziarah HÁ, Atkinson ME. The surgical anatomy of the cervical distribution of the facial nerve. Br J Oral Surg 1981;19:171-179.

12. Cranin AN, Brooklyn NY. Comparison of two submandibular incisions on the motor function of lower lip. Oral Surg Oral Med Oral Pathol 1975;40:327-332.

13. Ellis III E, Zide MF. Surgical approaches to facial skeleton. Philadelphia: Willians and Wilkins; 1995.

14. Fonseca RJ, Walker RV, Betts NJ, Barber HD. Oral and maxillofacial trauma. 2nd ed. vol 1. Philadelphia: Willians and Wilkins; 1997.

15. Touré S, Vacher C, Bertrand JC. Etude anatomique du rameau marginal de la mandibule du nerf facial. Rev Stomatol Chir Maxillofac 2004;105:149-152. 